\title{
Mitigation of free radicals and carbohydrate-linked enzymes by extracts and partitioned fractions of Elephantorrhiza elephantina (Burch.) Skeels root
}

\begin{tabular}{|c|c|}
\hline \multicolumn{2}{|c|}{$\begin{array}{l}\text { Authors: } \\
\text { Lebohang D. Moloi }{ }^{1} \\
\text { Fatai O. Balogun } \\
\text { Anofi O.T. Ashafa }\end{array}$} \\
\hline \multicolumn{2}{|c|}{$\begin{array}{l}\text { Affiliations: } \\
{ }^{1} \text { Department of Plant } \\
\text { Sciences, Faculty of Natural } \\
\text { and Agricultural Sciences, } \\
\text { University of the Free State, } \\
\text { Qwaqwa, South Africa }\end{array}$} \\
\hline \multicolumn{2}{|c|}{$\begin{array}{l}\text { Corresponding author: } \\
\text { Anofi Ashafa, } \\
\text { ashafaaot@ufs.ac.za }\end{array}$} \\
\hline \multicolumn{2}{|c|}{$\begin{array}{l}\text { Dates: } \\
\text { Received: } 05 \text { Mar. } 2021 \\
\text { Accepted: } 21 \text { May } 2021 \\
\text { Published: } 22 \text { July } 2021\end{array}$} \\
\hline \multicolumn{2}{|c|}{$\begin{array}{l}\text { How to cite this article: } \\
\text { Moloi, L.D., Balogun, F.O. \& } \\
\text { Ashafa, A.O.T., 2021, } \\
\text { 'Mitigation of free radicals and } \\
\text { carbohydrate-linked enzymes } \\
\text { by extracts and partitioned } \\
\text { fractions of Elephantorrhiza } \\
\text { elephantina (Burch.) Skeels } \\
\text { root', Journal of Medicinal } \\
\text { Plants for Economic } \\
\text { Development 5(1), a109. } \\
\text { https://doi.org/10.4102/ } \\
\text { jomped.v5i1.109 }\end{array}$} \\
\hline \multicolumn{2}{|c|}{$\begin{array}{l}\text { Copyright: } \\
\text { (C) 2021. The Authors. } \\
\text { Licensee: AOSIS. This work } \\
\text { is licensed under the } \\
\text { Creative Commons } \\
\text { Attribution License. }\end{array}$} \\
\hline \multicolumn{2}{|c|}{ Read online: } \\
\hline 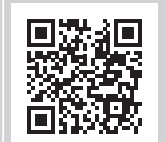 & $\begin{array}{l}\text { Scan this QR } \\
\text { code with your } \\
\text { smart phone or } \\
\text { mobile device } \\
\text { to read online. }\end{array}$ \\
\hline
\end{tabular}

Background: Elephantorrhiza elephantina (Burch.) Skeels is a medicinal plant used in folkloric medicine for the management of several metabolic and infectious diseases.

Aim: This aim of this research study was to investigate the antioxidant and antidiabetic effects of extracts and partitioned fractions in order to validate its folkloric use.

Setting: The plant material purchased from herb sellers in Qwaqwa township, authenticated at Department of Plant Science Qwaqwa herbarium, was evaluated in the same unit of the University of the Free State.

Methods: The antioxidative and antidiabetic activities of extracts and fractions were assessed with 1,1-diphenyl-2-picrylhydrazyl, 2,2-azino-bis(3-ethylbenzothiazoline-6)-sulphonic acid, hydroxyl radicals, metal chelating agents, and $\alpha$-amylase, as well as $\alpha$-glucosidase inhibitions based on standard methods. The subfractions with considerable yields from the partitioned n-hexane fraction of the crude extract were subjected to gas chromatography-mass spectrometry analysis or profiling for possible compound identification.

Results: The aqueous extract showed the most effective 1,1-diphenyl-2-picrylhydrazyl, hydroxyl radical and metal chelating activities judging by half-maximal inhibitory concentrations $\left(\mathrm{IC}_{50}: 0.573,0.059\right.$ and $1.937 \mathrm{mg} / \mathrm{mL}$, respectively), whilst the ethanol extract revealed maximum activity $(0.017 \mathrm{mg} / \mathrm{mL})$ against 2,2-azino-bis(3-ethylbenzothiazoline-6)sulphonic acid. However, the ethanol extract displayed the most potent alpha-amylase $(0.346 \mathrm{mg} / \mathrm{mL})$ inhibition, whilst the aqueous extract $(0.363 \mathrm{mg} / \mathrm{mL})$ was best against alpha-glucosidase. The modes of enzymes inhibition revealed that the aqueous extract displayed near-competitive inhibition against alpha-amylase and uncompetitive inhibition against alpha-glucosidase. Additionally, good antioxidative and antihyperglycaemic effects were established by the n-hexane fraction when compared with standards (gallic acid and acarbose). The GC-MS chromatogram of subfractions (4 and 9) from the n-hexane fraction afforded compounds, such as 2,4-bis (1, 1-dimethylethyl)-phenol, 9-octadecenoic acid (Z)-, methyl ester, dodecanoic acid and 1-methylethyl ester already established in the literature with potential pharmacological activities (antioxidant, anti-inflammatory, etc.).

Conclusion: The research study provides evidence on the folkloric use and insights on the prospect of the plant as natural antioxidative and antidiabetic agents.

Keywords: antioxidants; diabetes mellitus; Elephantorrhiza elephantine; free radicals; antihyperglycaemia.

\section{Introduction}

Elephantorrhiza elephantina (Burch.) Skeels is one of the prominent medicinal plants used in the treatment of several degenerative and infectious diseases (Maroyi 2017). The plant, belonging to the subfamily Mimosoideae of the family Fabaceae is a subshrub commonly known as elephant's root or eland's wattle. The perennial shrub plant is endowed with a stem that grows up to $0.9 \mathrm{~m}$ above the ground originating from a thick, woody rhizome. The leaves that appear dull-green in colour consist of two pinnate compounds of 2-17 oppositely arranged pinnae. The flowers, golden yellow or pale yellow or white, are arranged in axillary or solitary manner. Fruits are dark or reddish brown, with squeezed pods consisting of valves distinguishing them from continuous margins upon opening. Seeds are dark brown and ellipsoidal in shape (Grobler 2010; Olaokun et al. 2020). 
Elephantorrhiza elephantina is used by South Africans as a food source in medicine and other fields (e.g. the rhizome being used as a source of dye and tanning materials). Interestingly, because of its numerous medicinal properties, it is found mostly in muthi markets and across several provinces, such as Free State, Eastern Cape, Limpopo, Gauteng and Northern Cape, within South Africa. Traditionally, it is used for treating syphilis, internal disorders and to stop bleeding; these indigenous uses have been attributed to a variety of pharmacological and biological activities, such as antioxidant, antifungal, anthelmintic, antibacterial, antinociceptive, antiinflammatory and antiplasmodial (Maroyi 2017). It is worth mentioning that despite the use of the plant in Basotho traditional medicine for the management of diabetes mellitus (DM; Balogun, Tshabalala \& Ashafa 2016), there is a dearth of scientific information on its antidiabetic potential in the literature. Intriguingly, information gathered from the ethnobotanical survey on the use of these plants (Tshabalala \& Ashafa 2011), subsequently reviewed in the work of Balogun et al. (2016), suggested that only the root (rhizome) part of E. elephantina is used in the management of diabetes by the tribe.

Free radicals (nitrogen or oxygen) are cellular modulators produced within the body system (He \& Zou 2015). An increased free radical production results in a state of oxidative stress, leading to the development of many degenerative diseases (Liguori et al. 2018), including diabetes and its complications (Pieme et al. 2017). They attack cells or tissues resulting in the loss of body function. It must be noted that oxidative stress causes glucotoxicity by reducing insulin production from pancreatic beta cells and also disrupting the absorption of glucose into muscle cells (Chatterjee, Khunti \& Davies 2017).

Diabetes mellitus is a chronic derangement whose global prevalence has continued to increase, thus greatly affecting nations around the world (undeveloped, developing and developed) (Larijani \& Forozandeh 2003). It is a metabolic disorder characterised by hyperglycaemia, resulting in elevated glucose levels in the blood or urine arising from the inability of the pancreas to produce insulin (glucoseregulating hormone), which, in turn, leads to the abnormality in carbohydrate, protein and fat metabolism (Maiti et al. 2004). During the development of the disease, pathogenic processes come into play from the destruction of the pancreatic -cells to insulin resistance. These pathogenic processes have been established to be the primary cause of hyperglycaemia (high level of glucose in the blood) (Narkhede et al. 2011).

According to the International Diabetes Federation (IDF 2015), approximately 415 million of adult population around the world have diabetes, meaning that one in every 11 adults suffer from this ailment. In Africa, South Africa followed by Nigeria (in terms of prevalence per million populations) accounts for the highest incidence of diabetes, with about $6 \%$ of the entire population having diabetes (Balogun et al. 2016).
Additionally, an estimated 5 million people in South Africa have pre-diabetes (a condition where blood glucose levels are found to be higher than normal probably because of insulin resistance although not high enough to be classified as type 2 diabetes). The primary goal for the management of diabetes (pharmacological or non-pharmacological) is to control the blood glucose levels whilst preventing further complications of the disease. The pharmacological management involves the use of drugs or oral hypoglycaemic agents (OHAs), such as insulin, glibenclamide (sulphonylurea), metformin (biguanides) and acarbose, whilst the non-pharmacological activities include exercise regimen, dietary modification and healthy lifestyles. However, the use of these OHAs, particularly the alpha-glucosidase inhibitors, such as acarbose and voglibose, in the management of diabetes has been reported to be accompanied with debilitating gastrointestinal side effects, such as bloating and diarrhoea (Yin et al. 2014). There is a need to search for potent natural products with less toxic effects. Thus, this study is, therefore, aimed at evaluating the in vitro antioxidant and antidiabetic effects of the root of E. elephantina in order to search for suitable antidiabetic agents because of the adverse effects of synthetic ones.

\section{Materials and methods Chemicals}

Porcine pancreatic alpha-amylase, rat intestinal alphaglucosidase, 1, -diphenyl-2 picrylhydrazyl (DPPH), ascorbic acid, acarbose and para-nitrophenyl glucopyranoside (pNPG) were products obtained from Sigma-Aldrich Co. (St Louis, USA), whilst potato starch (extra pure) was obtained from J. T. Baker Inc. (Phillipsburg, USA). Other chemicals and reagents used were of analytical grade, and glass distilled water was used for the study.

\section{Collection, preparation and extraction of the plant materials}

The whole plant of E. elephantina was obtained from the herb sellers around the Free State Province. The authentication of the plant was performed by Professor AOT Ashafa from the University of Free State, Free State, South Africa. The E. elephantina sample was separated and washed under a running tap to remove all debris and chopped into small pieces before being dried in an oven for 9 days at $45^{\circ} \mathrm{C}$. The dried root material was then pulverised into fine powder using a Waring (instrument) Laboratory Blender. In the study involving the use of extracts, about $30 \mathrm{~g}$ each of the dried powdered material was exhaustively extracted in $900 \mathrm{~mL}$ each of distilled water (DW), ethanol and aqueous ethanol (ratio 1:1), respectively. The mixtures were then shaken constantly on a platform shaker (Labcon) at 110 revolutions per minute (rpm) for $72 \mathrm{~h}$, filtered using Whatman No 1 filter paper and concentrated the organic solvents under low pressure using a rotary evaporator (Cole-Palmer, model SB-1100 Shanghai, China) at $40{ }^{\circ} \mathrm{C}$, whilst the aqueous extract was lyophilised (VirTis BenchTop, SP Scientific, USA). The obtained extracts (1 g) 
were dissolved in dimethyl sulphoxide (DMSO) to obtain stock solutions of $1.0 \mathrm{mg} / \mathrm{mL}$, and different concentrations $(0.062 \mathrm{mg} / \mathrm{mL}, 0.125 \mathrm{mg} / \mathrm{mL}, 0.250 \mathrm{mg} / \mathrm{mL}, 0.500 \mathrm{mg} / \mathrm{mL}$ and $1.000 \mathrm{mg} / \mathrm{mL}$ ) of the extracts (working concentrations) were prepared by serial dilution with DW. All extracts were stored at $4^{\circ} \mathrm{C}$ prior to analysis.

The preparation for obtaining the fractions was carried out in the following way: approximately $500 \mathrm{~g}$ of the dried powdered material was exhaustively extracted with $1500 \mathrm{~mL}$ of DW (the choice of the solvent was based on the pharmacological study outcomes from the crude extract evaluation). The mixture was then shaken constantly on a platform shaker (Labcon) at $110 \mathrm{rpm}$ for $72 \mathrm{~h}$, filtered using Whatman No 1 filter paper and the extract was lyophilised (VirTis BenchTop, SP Scientific, USA) to obtain the crude extract, which was later dissolved in $550 \mathrm{~mL}$ of DW. The solution was partitioned in the order of increasing polarity with hexane $(1230 \mathrm{~mL})$, chloroform $(1430 \mathrm{~mL})$, ethyl acetate (1420 mL), n-butanol (1585 mL) and leftover (water); all designated as hexane fraction (HF), chloroform fraction (CF), ethyl acetate fraction (EF), butanol fraction (BF) and aqueous fraction (AF). The fractions were concentrated accordingly and evaluated for antioxidant and antidiabetic activities using the standard selected assays with the concentration range of $0.062-1.000 \mathrm{mg} / \mathrm{mL}$.

\section{In vitro antioxidant assays}

\section{1, 1-Diphenyl-2-picrylhydrazyl radical scavenging activity}

1, 1-Diphenyl-2-picrylhydrazyl radical scavenging activity of the samples (crude extracts and fractions) was evaluated based on the method of Saha et al. (2008) where the scavenging ability of the extracts was evaluated against $\mathrm{DPPH}$ (crystalline powder containing free radical molecules). In brief, $150 \mu \mathrm{L}$ of the various concentrations of the samples and/or standard (ascorbic acid) with $150 \mu \mathrm{L}$ of methanolic solution $(95 \%)$ DPPH radicals $(0.0004 \mathrm{~mol} / \mathrm{L})$ were mixed and left in the dark room for $30 \mathrm{~min}$. This was followed by measuring the absorbance at $515 \mathrm{~nm}$ using WPA BIOWAVE II (Bichrom, England) spectrophotometer. The whole procedure was similarly repeated for the control sample using DW to replace the extract.

\section{Hydroxyl radical scavenging activity}

The hydroxyl radical scavenging activity of the crude extract was analysed using the deoxyribose method based on Sindhu and Emilia's (2005) protocol. One hundred and twenty microlitres $(\mu \mathrm{L}) 0.2 \mathrm{M}$ of deoxyribose, $40 \mu \mathrm{L} 0.2 \mathrm{M} \mathrm{H}_{2} \mathrm{O}_{2^{\prime}}$ $400 \mu \mathrm{L} 0.1 \mathrm{M}$ phosphate buffer and $40 \mu \mathrm{L} 0.0005 \mathrm{M} \mathrm{FeSO}_{4}$ were mixed in $2 \mathrm{~mL}$ Eppendorf tubes, followed by the addition of $100 \mu \mathrm{L} \mathrm{DW}$, and the reaction mixture was incubated for $30 \mathrm{~min}$ at $37^{\circ} \mathrm{C}$. The reaction was stopped with $500 \mu \mathrm{L}$ of $2.8 \%$ trichloroacetic acid (TCA) and $400 \mu \mathrm{L}$ of $0.6 \%$ thiobarbituric acid (TBA). About $300 \mu \mathrm{L}$ from the mixture was pipetted and emptied into a 96-well microtitre plate, and the absorbance was measured at $532 \mathrm{~nm}$ using a microtitre plate reader (BIO-RAD, model 950).

\section{2, 2-Azino-bis(3-ethylbenzothiazoline-6-)sulphonic acid assay}

Adopting the method of Re, Pellegrini and Proteggente (1999), the scavenging ability of the samples against the azino-bis(3-ethylbenzothiazoline-6-)sulphonic acid (ABTS) radical was determined. Briefly, $7 \mathrm{mM}$ aq. ABTS and $2.45 \mathrm{mM}$ potassium persulphate $(50 \mathrm{~mL}$ each) were prepared and allowed to react in the dark for $16 \mathrm{~h}$. The reaction mixture was then adjusted with ethanol to $0.7 \mathrm{pH}$ at $734 \mathrm{~nm}$ using a spectrophotometer. Twenty microlitres of the sample were reacted with $200 \mu \mathrm{L}$ of ABTS-potassium persulphate mixture, and the absorbance was measured at $734 \mathrm{~nm}$.

\section{Metal chelating activity}

According to the method of Dinis, Madeira and Almeida (1994), the chelation of ferrous ions was estimated by the crude extracts. About $40 \mu \mathrm{L}$ of the extracts were readily mixed with $200 \mu \mathrm{L}$ of $2 \mathrm{mM} \mathrm{FeCl}_{2}$ solution in a 96-well microtiter plate; the reaction was started by adding $80 \mu \mathrm{L}$ of $5 \mathrm{mM}$ ferrozine, then shaken vigorously and the resulting mixture was left standing at room temperature for $10 \mathrm{~min}$. The absorbance of the reaction mixture was then assessed at $562 \mathrm{~nm}$ using a microplate reader (BIO-RAD, model 680, Japan).

\section{In vitro antidiabetic assays}

\section{$\alpha$-Glucosidase enzyme inhibition}

The varying concentrations of the samples $(50 \mu \mathrm{L})$ were mixed with $100 \mu \mathrm{L}$ of $0.1 \mathrm{~mol} / \mathrm{L}$ phosphate buffer ( $\mathrm{pH}$ 6.9) containing $\alpha$-glucosidase $(1.0 \mathrm{~mol} / \mathrm{L})$, and the mixture was incubated at $25{ }^{\circ} \mathrm{C}$ for $10 \mathrm{~min}$. Following this, $50 \mu \mathrm{L}$ of $0.1 \mathrm{~mol} / \mathrm{L}$ phosphate buffer having $5 \mathrm{mM}$ p-nitrophenyl- $\alpha$-D glucopyranoside ( $\mathrm{p}-\mathrm{NPG}$ ) was added to the solution at different time intervals, and the reaction mixture was incubated for $5 \mathrm{~min}$ at $25^{\circ} \mathrm{C}$. The absorbance was measured at $405 \mathrm{~nm}$, and the values were then compared with the standard (acarbose) obtained following the same steps above, although DW was used in place of the sample for the control or blank (Elsnoussi et al. 2012).

\section{$\alpha$-amylase enzyme inhibition}

About $100 \mu \mathrm{L}$ of $0.5 \mathrm{mg} / \mathrm{mL} \alpha$-amylase prepared in $0.02 \mathrm{M}$ sodium phosphate buffer (pH6.9) was mixed with $100 \mu \mathrm{L}$ of different concentrations of the samples in test tubes, and the reaction mixture was incubated at $25{ }^{\circ} \mathrm{C}$ for $10 \mathrm{~min}$. Thereafter, $100 \mu \mathrm{L}$ of $1 \%$ starch solution prepared with $0.02 \mathrm{M}$ sodium phosphate (buffer) was added to each tube at different time intervals to initiate the reaction. Following this, the mixture was again incubated at $25^{\circ} \mathrm{C}$ for $10 \mathrm{~min}$, and subsequently, $10 \mu \mathrm{L}$ of dinitrosalicylic acid (DNS) colour reagent was added to stop the reaction, and the reaction mixture was suspended in a hot $\left(100^{\circ} \mathrm{C}\right)$ water bath for $5 \mathrm{~min}$ and was cooled to room temperature. The absorbance was measured at $504 \mathrm{~nm}$ following the addition of $5 \mathrm{~mL} \mathrm{DW}$ into the mixture. Using the same concentrations as the samples, acarbose (prepared in DW) was utilised as a standard (Elsnoussi et al. 2012). 


\section{Mode of $\alpha$-glucosidase inhibition}

The kinetics of the inhibition of $\alpha$-glucosidase by an aqueous root extract of E. elephantina was determined using a modified method of Dnyaneshwar and Archana (2013) with a slight modification. Briefly, $5 \mathrm{mg} / \mathrm{mL}$ of the extract $(25 \mu \mathrm{L})$ was preincubated with $50 \mu \mathrm{L}$ of $\alpha$-glucosidase solution for $10 \mathrm{~min}$ at $25{ }^{\circ} \mathrm{C}$ in one set of test tubes. In another set of tubes, $\alpha$-glucosidase was pre-incubated with $25 \mu \mathrm{L}$ of phosphate buffer (pH 6.9). Twenty-five microlitres of pNPG at increasing concentrations $(0.25-2.00 \mathrm{mg} / \mathrm{mL})$ were added to both sets of reaction mixtures to start the reaction. Whilst the mixture was incubated for $10 \mathrm{~min}$ at $25^{\circ} \mathrm{C}, 170 \mu \mathrm{L}$ of $\mathrm{Na}_{2} \mathrm{CO}_{3}$ was added to stop the reaction. The amount of reducing sugars released was determined colourimetrically using a $p$-nitrophenol standard curve. Reaction rates or velocity (V) was calculated, and the double reciprocal plots of enzyme kinetics were constructed according to the Lineweaver and Burk method in order to study the nature of inhibition. $\mathrm{K}_{\mathrm{m}}$ and $\mathrm{V}_{\max }$ values were also calculated from the LineweaverBurk plot (1/V vs. 1/[S]).

\section{Mode of $\alpha$-amylase inhibition}

The kinetics of alpha-amylase inhibition was determined using a modified method of Ali, Houghton and Soumyanath (2006). Briefly, $250 \mu \mathrm{L}$ of the extract $(5 \mathrm{mg} / \mathrm{mL}$ ) was preincubated with $250 \mu \mathrm{L}$ of $\alpha$-amylase solution for $10 \mathrm{~min}$ at $25^{\circ} \mathrm{C}$ in one set of tubes, whilst $\alpha$-amylase $(0.5 \mathrm{mg} / \mathrm{mL})$ was pre-incubated with $250 \mu \mathrm{L}$ of phosphate buffer $(\mathrm{pH}$ 6.9) in another set of tubes. The reaction of the two sets of the mixtures was initiated by adding $250 \mu \mathrm{L}$ of the starch solution at increasing concentrations $(0.31-5.00 \mathrm{mg} / \mathrm{mL})$. The mixture was then incubated for $10 \mathrm{~min}$ at $25{ }^{\circ} \mathrm{C}$, followed by the addition of DNS $(500 \mu \mathrm{L})$, boiled for $5 \mathrm{~min}$ and then $2.5 \mathrm{~mL}$ DW was finally added to dilute the mixture. The amount of reducing sugars released was determined spectrophotometrically using a maltose standard curve and converted to reaction velocities. A double reciprocal (Lineweaver-Burk) plot (1/V vs. $1 /[\mathrm{S}])$, where $\mathrm{V}$ is the reaction velocity and $[S]$ is substrate concentration, was plotted to determine the mode of inhibition.

\section{Percentage inhibitory determinations}

The inhibitory activity of the samples was calculated by adopting the following expression: $A b_{0}-A b_{1} / A b_{0} \times 100$, where $A b_{0}$ is the absorbance of the control and $A b_{1}$ is the absorbance of the sample or standard. The half-maximal inhibitory concentration $\left(\mathrm{IC}_{50}\right)$ value was calculated from the linear regression equation using $\mathrm{y}=\mathrm{mx}+\mathrm{c}$, where $\mathrm{y}$ is the percentage activity and equals to $50, \mathrm{~m}$ connotes the slope, $c$ signifies the intercept and $x$ represents the $\mathrm{IC}_{50}$ value (Balogun \& Ashafa 2016).

\section{Chromatographic analysis}

The n-hexane fraction being the most active was subjected to chromatographic separation using the silica gel (100-200 mesh size) column and the mixture of chloroform and ethanol in varying ratios as the mobile phase. Briefly, silica gel (150 g) was mixed with about $300 \mathrm{~mL}$ of $100 \%$ chloroform to form a homogenous suspension or slurry, and the mixture was stirred using a glass-stirring rod to remove bubbles. The slurry was poured time to time into the column (closed at the tail end with cotton wool) very carefully to form a uniform packing (to prevent cracking of silica), and this was allowed to stand for $24 \mathrm{~h}$ so as to equilibrate. Then, a slurry of the n-hexane fraction (5.03 g) with a small amount of silica gel prepared was applied carefully on the top layer of the packed column and successfully eluted with solvent or solvent system chosen (Barbara 2014; Natarajan 2015). The ratio of solvent system (chloroform: ethanol) prepared $(250 \mathrm{~mL})$ was 10:0, 9:1, 8:2, 7:3, 6:4, 5:5, 4:6, 3:7, 2:8 and 1:9. Eluents (134 fractions) were collected in numbered conical flasks $(20 \mathrm{~mL})$, concentrated by air-drying and bulked using TLC profiles of each fraction to obtain 15 subfractions.

\section{Preparative Thin-Layer Chromatography}

A streak of subfractions 4 and 9 (chosen based on the yield) were loaded onto a TLC plate $(20 \mathrm{~cm} \times 10 \mathrm{~cm}$ diameter and thickness of $1.5 \mathrm{~mm}$ ), dried using a hair hand-dryer and then developed in a chromatographic glass chamber containing the mobile phases, such as chloroform-ethanol-acetic acid (ration 4:1:3 drops) for subfraction 4 and chloroform-ethanol (3:2) for subfraction 9. For each set of the fractions, four plates $(20 \times 10)$ were used and a plate each (out of the 4$)$ was sprayed with anisaldehyde-sulphuric acid spraying reagent (followed by exposure to heat at $110^{\circ} \mathrm{C}$ for few minutes) to identify bands where the scrapping on the remaining three plates were carried out. The scrapped samples were extracted with methanol and chloroform (30 mL each), filtered, concentrated (by reducing the volume of the extracting solvents) and later sent for gas chromatography-mass spectroscopy (GCMS) analysis following a second round of pTLC processes (involving re-spotting, development and visualisation) in order to confirm the purity of the identified compound.

\section{Gas chromatography-mass spectroscopy}

All the samples by GC-MS were analysed using Perkin Emler ${ }^{\circledR}$ gas chromatography (Clarus ${ }^{\circledR} 580$ ) functioning with a mass selective detector (MSD) mass spectrophotometer (Clarus ${ }^{\circledR} \mathrm{SQ8S}$ ) instrument that has a built-in auto-sampler. The samples were analysed on an Elite- $5 \mathrm{~ms}(30 \mathrm{~m} \times 0.25 \mathrm{~mm}$ internal diameter $\times 0.25 \mu \mathrm{m}$ ) column. Oven temperature was programmed to progress from $37{ }^{\circ} \mathrm{C}$ to $320^{\circ} \mathrm{C}$ at a rate of $18^{\circ} \mathrm{C} / \mathrm{min}-25^{\circ} \mathrm{C} / \mathrm{min}$ and delayed for 0.5 and $1.85 \mathrm{~min}$ at $18^{\circ} \mathrm{C}$ and $320^{\circ} \mathrm{C}$, respectively. The temperature of the injector was $250^{\circ} \mathrm{C}$ with the MS ion source temperature being $280^{\circ} \mathrm{C}$, with a full scan and solvent delay of $0.00-2.30 \mathrm{~min}$. The MS scan range was m/z 35-500 in $0.10 \mathrm{sec}$. One microlitre of each sample was injected at a split flow rate of $20 \mathrm{~mL} / \mathrm{min}$ in helium carrier gas.

\section{Statistical analysis}

Data analyses were performed by one-way analysis of variance (ANOVA), followed by Bonferroni's multiple 
comparison test, and the results were expressed as mean \pm standard error of mean (SEM) using Graph Pad Prism, version 3.0 for Windows, Graph Pad Software, San Diego, California, USA. A value of $p<0.05$ was considered to be statistically significant.

\section{Results \\ Sample yield}

Table 1 reveals the yields and percentage yields of the extracts and fractions. Aqueous ethanol and hexane were found to produce the highest yields amongst the crude extract (9.18 g) and fractions (20.03), respectively.

\section{Antioxidant assays}

The $\mathrm{IC}_{50}$ values for the free radical scavenging abilities of the root extracts of E. elephantina are presented in Table 2. The aqueous extract displayed the best radical (DPPH) scavenging and metal-chelating effects, judging by its lowest $\mathrm{IC}_{50}$ values $(0.573 \mathrm{mg} / \mathrm{mL}$ and $1.937 \mathrm{mg} / \mathrm{mL}$, respectively), which was insignificantly lower $(p>0.05)$ compared with other extracts, except for ascorbic acid, having $(p<0.05) \mathrm{IC}_{50}$ values of $1.439 \mathrm{mg} / \mathrm{mL}$ and $0.282 \mathrm{mg} / \mathrm{mL}$ respectively.

TABLE 1: Yield of crude extracts and partitioned fractions of E. elephantina root.

\begin{tabular}{lcc}
\hline Extracts/Fractions & Yield (g) & Yield (\%) \\
\hline Crude extracts & & \\
Aqueous & 4.86 & 16.2 \\
Ethanol & 7.08 & 23.6 \\
Aqueous-ethanol & 9.18 & 30.6 \\
Partitioned fractions & & \\
Hexane & 20.03 & 21.5 \\
Chloroform & 15.25 & 16.4 \\
Ethyl acetate & 14.00 & 15.1 \\
Butanol & 13.59 & 14.6 \\
Aqueous & 13.05 & 14.0 \\
\hline
\end{tabular}

Note: The yield of crude extracts from aqueous ethanol was found to give the highest with $9.18 \mathrm{~g}$ followed by ethanol $(7.08 \mathrm{~g})$ and finally aqueous $(4.86 \mathrm{~g})$ corresponding to percentage yields of 30.6, 23.6 and 16.2, respectively (Table 1). Additionally, a total yield of $93.04 \mathrm{~g}$ corresponding to a percentage yield of 18.61 obtained for the partitioning study.

TABLE 2: Free radical scavenging and metal chelating abilities of different extracts and fractions of E. elephantina root.

\begin{tabular}{lcccc}
\hline Variable & \multicolumn{4}{c}{ Antidiabetic assays $\left(\mathrm{IC}_{50}[\mathrm{mg} / \mathrm{mL}]\right)$} \\
\cline { 2 - 5 } & DPPH & Hydroxyl radical & ABTS & Metal chelating \\
\hline Extracts $\dagger$ & & & & \\
Ethanol & $0.855 \pm 0.111^{\mathrm{a}}$ & $0.641 \pm 0.048^{\mathrm{a}}$ & $0.017 \pm 0.243^{\mathrm{a}}$ & $7.261 \pm 5.567^{\mathrm{a}}$ \\
Aqueous ethanol & $0.834 \pm 0.072^{\mathrm{a}}$ & $0.596 \pm 0.052^{\mathrm{a}}$ & $9.468 \pm 8.089^{\mathrm{b}}$ & $3.209 \pm 5.567^{\mathrm{b}}$ \\
Aqueous & $0.573 \pm 0.001^{\mathrm{b}}$ & $0.059 \pm 0.026^{\mathrm{b}}$ & $2.126 \pm 2.605^{\mathrm{c}}$ & $1.937 \pm 0.411^{\mathrm{c}}$ \\
Ascorbic acid & $1.439 \pm 2.827^{\mathrm{c}}$ & $1.419 \pm 3.803^{\mathrm{c}}$ & $35.52 \pm 24.27^{\mathrm{d}}$ & $0.282 \pm 0.039^{\mathrm{d}}$ \\
Fractions $\dagger$ & & & & \\
Hexane & $0.171 \pm 0.46^{\mathrm{a}}$ & $\mathrm{ND}$ & $0.170 \pm 0.55^{\mathrm{a}}$ & $\mathrm{ND}$ \\
Chloroform & $0.226 \pm 0.15^{\mathrm{b}}$ & $\mathrm{ND}$ & $0.236 \pm 0.55^{\mathrm{b}}$ & $\mathrm{ND}$ \\
Ethyl acetate & $0.583 \pm 0.58^{\mathrm{c}}$ & $\mathrm{ND}$ & $1.189 \pm 0.02^{\mathrm{c}}$ & $\mathrm{ND}$ \\
Butanol & $0.445 \pm 0.22^{\mathrm{d}}$ & $\mathrm{ND}$ & $0.397 \pm 0.58^{\mathrm{d}}$ & ND \\
Aqueous & $0.154 \pm 0.51^{\mathrm{a}}$ & $\mathrm{ND}$ & $0.216 \pm 0.34^{\mathrm{b}}$ & ND \\
Gallic acid & $0.497 \pm 0.51^{\mathrm{e}}$ & $\mathrm{ND}$ & $0.434 \pm 0.58^{\mathrm{e}}$ & ND \\
\hline
\end{tabular}

Note: The values are expressed as mean \pm standard error of mean (SEM) of triplicate determinations.

ABTS, 2,2-azino-bis (3-ethylbenzothiazoline-6-sulphonic acid; DPPH, 1.1-diphenyl-2picrylhydrazyl; ND, not determined; $I_{5}$, inhibitory concentrations.

$\dagger$, Values with different superscript letters along the same rows for each parameter are significantly different from each other at $p<0.05$.
Similarly for hydroxyl radical assay, the aqueous extract displayed the lowest $\mathrm{IC}_{50}$ value $(0.059 \mathrm{mg} / \mathrm{mL})$, which is significantly lower $(p<0.05)$ than the other extracts and the standard, indicating a better activity. The ethanol extract exhibited the lowest $\mathrm{IC}_{50}$ value $(0.017 \mathrm{mg} / \mathrm{mL})$ compared with other extracts and ascorbic acid, signifying the most potent effect against the ABTS radical. Overall, the aqueous extract showed the best free radical scavenging effect by inhibiting the activities of these radicals in three of the four evaluated assays.

As shown in Table 2, HF, however, revealed the best radical scavenging effect against DPPH and ABTS. This was observed by its lower $\mathrm{IC}_{50}$ value $(0.171 \mathrm{mg} / \mathrm{mL})$ for $\mathrm{DPPH}$ and the lowest ABTS $(0.170 \mathrm{mg} / \mathrm{mL}) \mathrm{IC}_{50}$ values. The activity was followed by $\mathrm{AF}$, with $\mathrm{IC}_{50}$ values of $0.154 \mathrm{mg} / \mathrm{mL}$ and $0.216 \mathrm{mg} / \mathrm{mL}$, respectively, whilst the least inhibition was observed in $\mathrm{EF}$, with the $\mathrm{IC}_{50}$ values of $0.583 \mathrm{mg} / \mathrm{mL}$ and $1.189 \mathrm{mg} / \mathrm{mL}$, respectively.

\section{Antidiabetic assays}

Root extracts of E. elephantina showed good inhibitory activities against the carbohydrate-hydrolysing enzymes, such as $\alpha$-amylase and $\alpha$-glucosidase, as shown in Table 3. The aqueous extract of E. elephantina exhibited the highest inhibition of the activity of $\alpha$-glucosidase indicated by the lowest $\mathrm{IC}_{50}$ value $(0.363 \mathrm{mg} / \mathrm{mL})$, which was significantly lower $(p<0.05)$ than other extracts and the standard. However, for alpha-amylase, the ethanol extract revealed the lowest $\mathrm{IC}_{50}$ value $(0.346 \mathrm{mg} / \mathrm{mL})$, suggesting its ability to strongly inhibit the enzyme. The inhibition is followed by aqueous ethanol $(0.391 \mathrm{mg} / \mathrm{mL})$ and finally aqueous $(0.453 \mathrm{mg} / \mathrm{mL})$. The modes of inhibitions of $\alpha$-amylase and $\alpha$-glucosidase, as shown in Figures 1 and 2, respectively, by the aqueous root extract of E. elephantina showed a near-competitive inhibition towards $\alpha$-amylase, signifying a close $\mathrm{V}_{\max }$ value $(0.16 \mathrm{mM} / \mathrm{min})$ between the control and the extract with a decrease in $\mathrm{K}_{\mathrm{m}}$ values from 0.182 (extract) to 0.156 (control) $\mathrm{mM}^{-1}$ (Figure 1). For

TABLE 3: E. elephantina root extenuates the activities of carbohydrate-hydrolysing enzymes.

\begin{tabular}{lcc}
\hline Variable & \multicolumn{2}{c}{ Antidiabetic assays $\left(\mathrm{IC}_{50}[\mathrm{mg} / \mathrm{mL}]\right)$} \\
\cline { 2 - 3 } Extracts & $\alpha$-glucosidase & $\alpha$-amylase \\
Ethanol & $0.739 \pm 0.091^{\mathrm{a}}$ & $0.346 \pm 0.107^{\mathrm{a}}$ \\
Aqueous ethanol & $0.536 \pm 0.032^{\mathrm{b}}$ & $0.391 \pm 0.079^{\mathrm{a}}$ \\
Aqueous & $0.363 \pm 0.038^{\mathrm{c}}$ & $0.453 \pm 0.018^{\mathrm{b}}$ \\
Acarbose & $45.77 \pm 51.24^{\mathrm{d}}$ & $4.178 \pm 1.327^{\mathrm{c}}$ \\
Fractions & & \\
Hexane & $0.894 \pm 0.52^{\mathrm{a}}$ & $4.373 \pm 0.35^{\mathrm{a}}$ \\
Chloroform & $0.813 \pm 0.32^{\mathrm{a}}$ & $1.793 \pm 0.20^{\mathrm{b}}$ \\
Ethyl acetate & $0.361 \pm 0.53^{\mathrm{b}}$ & $4.101 \pm 0.03^{\mathrm{c}}$ \\
Butanol & $1.031 \pm 0.25^{\mathrm{c}}$ & $2.212 \pm 0.02^{\mathrm{d}}$ \\
Aqueous & $2.115 \pm 0.79^{\mathrm{d}}$ & $5.591 \pm 0.59^{\mathrm{e}}$ \\
Acarbose & $2.621 \pm 0.02^{\mathrm{d}}$ & $1.697 \pm 0.18^{\mathrm{b}}$ \\
\hline
\end{tabular}

Note: Values are expressed as mean \pm standard error of mean (SEM) of triplicate determinations. Values bearing different superscript along the same row for each parameter are significantly different from each other at $p<0.05$.

$\alpha$, alpha; $\mathrm{IC}_{50}$, inhibitory concentrations. 
$\alpha$-glucosidase, it was uncompetitively inhibited with a decrease in Vmax values from 0.005 (extract) to 0.0005 (control) $\mathrm{mM} / \mathrm{min}$ and $\mathrm{Km}$ values from 0.038 (extract) to 0.004 (control) $\mathrm{mM}^{-1}$ between the extract and the control (Figure 2).

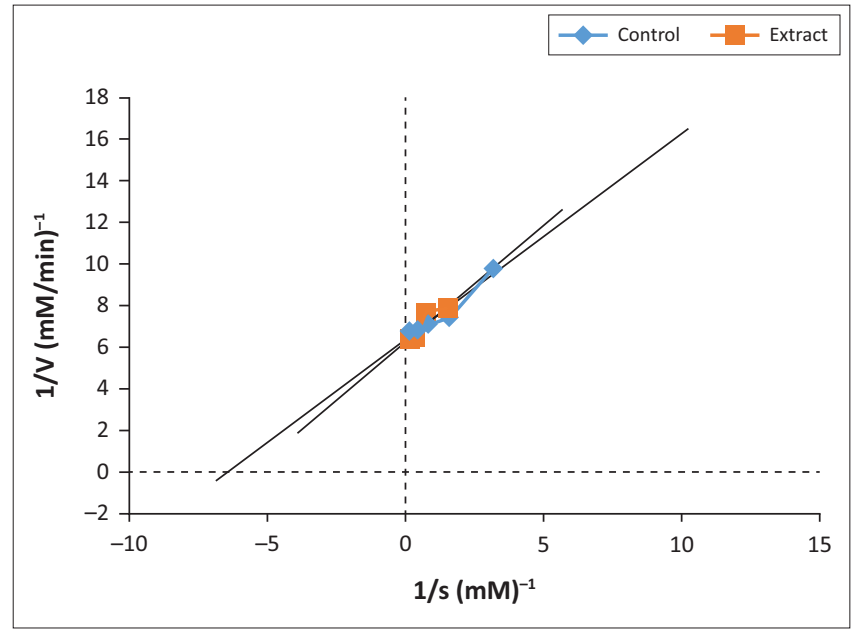

FIGURE 1: Mode of inhibition of $\alpha$-amylase by aqueous root extract of E. elephantina showing a near-competitive inhibition.

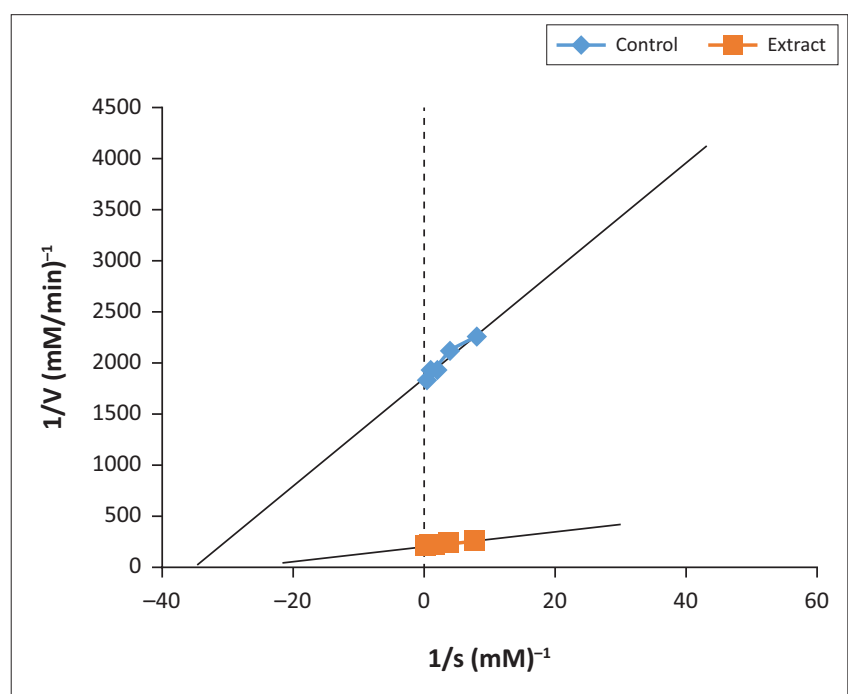

FIGURE 2: Mode of inhibition of $\alpha$-glucosidase by aqueous extract of E. elephantina root revealing an uncompetitive inhibition.
The fractions of E. elephantina showed mild-to-moderate inhibitory activities against the carbohydrate-hydrolysing enzymes, such as $\alpha$-glucosidase and $\alpha$-amylase, as shown in Table 3. Ethyl acetate $(0.361 \mathrm{mg} / \mathrm{mL})$, chloroform $(0.813 \mathrm{mg} / \mathrm{mL})$ and hexane $(0.894 \mathrm{mg} / \mathrm{mL})$ fractions going by $\mathrm{IC}_{50}$ reported the lowest values against $\alpha$-glucosidase, revealing better activities than the standard, acarbose $(2.621$ $\mathrm{mg} / \mathrm{mL}$ ). Acarbose $(1.697 \mathrm{mg} / \mathrm{mL})$, however, followed by chloroform $(1.793 \mathrm{mg} / \mathrm{mL})$ and butanol $(2.212 \mathrm{mg} / \mathrm{mL})$ displayed the lowest $\mathrm{IC}_{50}$ values in the inhibition of $\alpha$-amylase activity.

\section{Chromatographic reports}

The column chromatography of HFs produced 134 fractions, and based on the chromatographic features of each fraction on TLC, they were pooled together to afford 15 subfractions. The subfractions 4 and 9 were further analysed using chloroform: ethanol: acetic acid (4:1:3 drops) (for subfraction 4) and chloroform: ethanol (3:2) (subfraction 9) solvent systems, where a prospective spot was obtained for further analysis. The GCMS chromatogram for subfraction 4 revealed a number of phytoconstituents, such as triphenylphosphine oxide, with $46.86 \%$ abundance for subfraction 4 (Table 4), whilst subfraction 9 depicted 1-Tetracosanol (20.65\%) (Table 5).

\section{Discussion}

Free radicals could be toxic and, at the same time, beneficial to the human body; this is because at low levels, they can be helpful for maintaining cellular responses and immune function. However, a state of oxidative stress may be induced as a result of its excessive generation in the human body, leading to the destruction of body biomolecules, such as proteins, lipids, carbohydrates and deoxyribonucleic acid (DNA) (Lobo et al. 2010; Young \& Woodside 2001). Intriguingly, many of the human degenerative diseases, such as DM and cancer, (Szalay 2016), are reported to be triggered by excessive production of free radicals (Satlisha, Lingaraju \& Sham Prasad 2011). Hence, prompt intervention of an antioxidant, particularly those arising from natural products, may come handy in neutralising the ravishing effects of

TABLE 4: Depicted phytoconstituents from gas chromatography-mass spectroscopy chromatogram of subfraction 4.

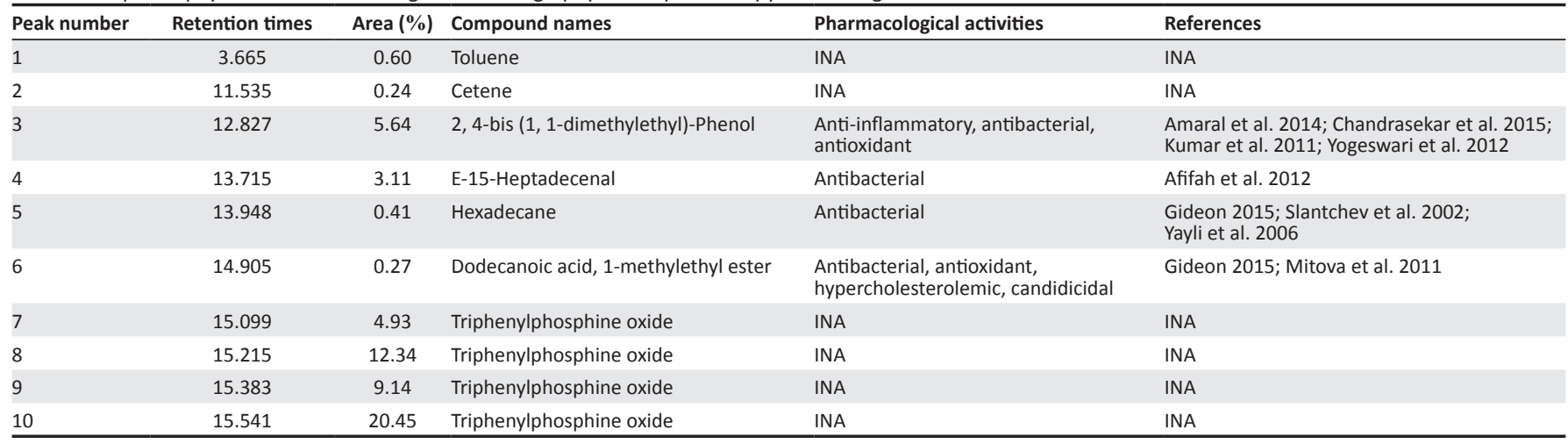


TABLE 5: Identified phytoconstituents in the chromatogram of subfraction 9.

\begin{tabular}{|c|c|c|c|c|c|}
\hline Peak number & Retention times & Area $(\%)$ & Compound names & Pharmacological activities & References \\
\hline 1 & 3.701 & 0.84 & Toluene & INA & INA \\
\hline 2 & 11.536 & 0.64 & 1-Tetradecene & INA & INA \\
\hline 3 & 12.829 & 20.56 & 2,4-Bis (1,1-dimethylethyl)-phenol & $\begin{array}{l}\text { Anti-inflammatory, antibacterial, } \\
\text { antioxidant }\end{array}$ & $\begin{array}{l}\text { Amaral et al. 2014; Chandrasekar et al. 2015; } \\
\text { Kumar et al. 2011; Yogeswari et al. } 2012\end{array}$ \\
\hline 4 & 13.645 & 5.66 & Tetradecyl trifluoroacetate & INA & INA \\
\hline 5 & 13.715 & 0.92 & Hexadecane & Antibacterial & $\begin{array}{l}\text { Gideon 2015; Slantchev et al. 2002; } \\
\text { Yayli et al. } 2006\end{array}$ \\
\hline 7 & 14.624 & 2.24 & 2-Propenoic acid, pentadecyl ester & INA & INA \\
\hline 8 & 15.768 & 17.40 & Trifluoroacetic acid, pentadecyl ester & INA & INA \\
\hline 9 & 15.847 & 3.38 & Heptadecane & INA & INA \\
\hline 10 & 17.869 & 3.73 & $\begin{array}{l}\text { Benzenepropanoic acid, 3,5-bis(1,1- } \\
\text { dimethylethyl)-4-hydroxy-, methyl ester }\end{array}$ & INA & INA \\
\hline 11 & 19.161 & 20.65 & n-Tetracosanol-1 & Antibacterial & Kuppuswamy et al. 2013 \\
\hline 13 & 21.750 & 1.43 & Methyl 10-trans,12-cis-octadecadienoate & INA & INA \\
\hline 14 & 21.974 & 1.67 & 9-Octadecenoic acid (Z)-, methyl ester & $\begin{array}{l}\text { Antimicrobial, anti-inflammatory, } \\
\text { cancer preventative }\end{array}$ & $\begin{array}{l}\text { Gideon 2015; Simin et al. 2000; } \\
\text { Wagh et al. } 2007\end{array}$ \\
\hline 15 & 22.644 & 5.65 & $\begin{array}{l}\text { [1,1'-Biphenyl]-2,3'-diol, } \\
\text { 3,4',5,6'-tetrakis(1,1-dimethylethyl)- }\end{array}$ & INA & INA \\
\hline
\end{tabular}

INA, information not available.

Note: Please see the full reference list of the article, Moloi, L.D, Balogun, F.O. \& Ashafa, A.O.T., 2021, 'Mitigation of free radicals and carbohydrate-linked enzymes by extracts and partitioned fractions of Elephantorrhiza elephantina (Burch.) Skeels root', Journal of Medicinal Plants for Economic Development 5(1), a109. https://doi.org/10.4102/jomped.v5i1.109, for more information.

these free radicals. This study evaluated the antioxidant and antidiabetic potentials of different extracts and fractions of E. elephantina roots. The results of this investigation revealed that the aqueous extract of E. elephantina exhibited the best activity in scavenging free radicals (DPPH and hydroxyl radical) and also chelate metal ions. Thus, indicating its excellent antioxidant and disease-control capacities since it has been reported that hydroxyl radical is one of the major oxygencontaining free radicals resulting in the ontogenesis of many diseases (Lobo et al. 2010). Moreover, the ability of the aqueous extract to wipe the $\mathrm{DPPH}$ and $\mathrm{OH}^{-}$radical partly suggests the tendency of the extract to decolorise DPPH with the potential ability to scavenge DPPH radicals. Aside the fact that the result corroborated the findings of Mpofu et al. (2014) on the scavenging ability of DPPH radical by the aqueous root extract, it may be suggested that the antioxidative potential might be attributed to phenolic compounds in the extract of the plant (Olaokun et al. 2020), which might be irrespective of the plant parts as the hot leaf extract similarly in a recent study by Olaokun et al. (2020) inhibited DPPH and ABTS radicals. Additionally, the ethanol extract reported the lowest $\mathrm{IC}_{50}$ value for ABTS, indicating that the extract also has the ability to scavenge the free radical and prevent oxidative stress. Judging by the revelation in this study and other reports (Mpofu et al. 2014; Olaokun et al. 2020), it could be deduced that the use of polar solvents (aqueous, ethanol and methanol) maximally extracts antioxidative polar compounds. This is best felt or established with the aqueous extract when compared with the other polar solvent (ethanol) in this study; however, the reverse is the case with the study of Mpofu et al. (2014) where the methanol extract exhibited a superior radical scavenging effect compared with the aqueous extract. The variation might be attributed to differences in methods. In line with the aforementioned results, the observed activity of HF (from the crude aqueous extract) against ABTS and DPPH (although AF highly inhibited DPPH) followed by CF may be suggestive of the antioxidant potential of the plant across solvent ranges (polar and non-polar).

Alpha-glucosidase is a carbohydrate-hydrolysing enzyme found in the brush border of the small intestine. It functions by breaking down disaccharides into glucose. The control of postprandial hyperglycaemia is very crucial in the treatment of diabetes and its associated complications. Hence, there is an absolute need for regulating enzymes, such as $\alpha$-glucosidase and $\alpha$-amylase, involved in the constant metabolism of carbohydrates to glucose (Kwon et al. 2007). In this study, the aqueous extract of E. elephantina displayed the strongest inhibition of $\alpha$-glucosidase. This was exhibited by its lowest $\mathrm{IC}_{50}$ value for the enzyme, which is lower than that for acarbose (a known antihyperglycaemic agent). A strong inhibition of $\alpha$-glucosidase is one of the features of an antidiabetic agent (Kwon et al. 2007). However, the findings of this study contradict the report of Olaokun et al. (2020) where ethanol and aqueous (cold) leaf extracts are the weakest inhibitors of the enzyme. Notwithstanding the aforementioned findings, the result of this study is in consonance with the report of Kazeem and Ashafa (2015) where the aqueous extract of Dianthus basuticus reported a strong inhibition against $\alpha$-glucosidase, which consequently may be attributed to the antioxidant activity of the aqueous extract of the plant. Alpha-amylase is found in the saliva and pancreas, and it catalyses the conversion of polysaccharides to disaccharides (Manohar et al. 2002). Thus, a good inhibitor of this enzyme would go a long way in slowing down its activity, and for this to happen, the extract or the inhibitor should have the capacity to inhibit the enzyme mildly to be considered a good antidiabetic agent. Mild inhibition is depicted by an extract with a higher $\mathrm{IC}_{50}$ value for $\alpha$-amylase. Although it is worth mentioning that the ethanol extract 
was the strongest inhibitor of this enzyme in this study as similarly reflected in the work of Olaokun et al. (2020), however, the aqueous extract displayed mildest inhibition depicted by its highest $\mathrm{IC}_{50}$ value of $0.453 \mathrm{mg} / \mathrm{mL}$; this makes it suitable for use as a potent hypoglycaemic agent better than the synthetic agent. Generally, a good antidiabetic agent with the possibility of being effective above OHAs (such as acarbose and miglitol) without revealing any adverse side effects, such as constipation and bloating, should be a mild inhibitor of alpha-amylase and a strong inhibitor of alpha-glucosidase. The findings of the study regarding the crude extract (aqueous) were also corroborated or consolidated by HF, which depicted strong alphaglucosidase and mild alpha-amylase inhibitions. Thus, this was in line with the aforementioned antioxidant potential of the fraction and the effectiveness of varying solvent ranges (polar and non-polar alike). The antidiabetic activity of medicinal plants (such as Cucumis prophetarum) partitionednon-polar solvents (chloroform, hexane, etc.) has been reported (Gawli \& Lakshimidevi 2015).

The Lineweaver-Burk plot otherwise known as a double reciprocal plot is a graphical representation described by Hans Lineweaver and Dean Burk to reflect and or analyse the (Michaelis-Menten) equation for understanding the kinetics of enzyme inhibition, which can be competitive, uncompetitive and non-competitive. In fact, the plot helps in determining important parameters, such as maximum reaction velocity $\left(\mathrm{V}_{\max }\right)$ and $\mathrm{K}_{\mathrm{m}^{\prime}}$ which is the MichaelisMenten constant. In this study, the possible kinetics of inhibition of $\alpha$-amylase by the aqueous root extract of E. elephantina depicts a near-competitive inhibition, suggesting that the active components of the extract may bind reversibly to the active site of the enzyme. This shows that the extract has a potential to slow down the breakdown of oligosaccharides to disaccharides. Moreover, the extract displayed an uncompetitive inhibition against $\alpha$-glucosidase, implying that the active components of the extract binds to the other sites of the enzyme-substrate complex, resulting in the slowing down of disaccharide synthesis to glucose (Cornish-Bowden 2013).

The GC-MS chromatograms of E. elephantina (subfractions 4 \& 9) revealed the presence of seven major phytochemicals, including triphenylphosphine oxide, 2,4-bis (1,1-dimethylethyl)-phenol, E-15-heptadecenal, hexadecane, 1-methylethyl ester dodecanoic acid, cetene, toluene (subfraction 4) and 2,4-bis (1,1-dimethylethyl)-phenol, tetradecyl trifluoroacetate, 1-tetradecene, hexadecane, 1-methylethyl ester dodecanoic acid, pentadecyl ester 2-propenoic acid, heptadecane, methyl ester benzenepropanoic acid, n-tetracosanol, heneicosane, methyl 10-trans,12-cisoctadecadienoate and (Z)-, methyl ester 9-octadecenoic acid. A number of these chemical components have established pharmacological potentials. Typically, 2,4-bis (1,1-dimethylethyl)-phenol found in both the subfractions is reported to possess anti-inflammatory (Amaral et al. 2014; Chandrasekar et al. 2015; Kumar, Bhatnagar \& Srivastava 2011; Yogeswari etal. 2012), neuronal and antioxidant
(Yang et al. 2016) effects. The 2,4-di-tert-butylphenol plays a significant role as an antioxidant and marine metabolite (NLM 2020). Z-Methyl 9-octadecenoic acid was found to act as anti-inflammatory and anticancer agents (Gideon 2015), whilst 1-methyllethyl ester dodecanoic acid possessed antioxidant and hypercholesterolaemic activities (Gideon 2015; Mitova et al. 2011), which is suggestive of antihyperglycaemiceffect of the plantas hypercholesterolemia is one of the risk factors or complications of diabetes.

\section{Conclusion}

The results of this investigation revealed that the extracts and fractions of E. elephantina possessed antioxidant and antidiabetic effects in vitro. A possible mechanism of antidiabetic effect of this plant could be through the inhibition of diabetes-related enzymes. Therefore, it could be inferred that the study supports the traditional use of E. elephantina in the management of diabetes in the eastern Free State Province of South Africa.

Furthermore, with this submission, research work on pharmacological potentials (especially against diabetes and safety profile) of the plant in animal models is on-going, which to our understanding would go a long way in efforts towards developing a drug moiety against diabetes in order to fully elucidate the potentials of the plant. Additionally, as GC-MS may not be the only technique required for the identification of the active compounds responsible for the elicited effects; hence, isolation and characterisation of the plant involving additional techniques, such as mass spectrophotometry and nuclear magnetic resonance (carbon 1 and 13), are recommended.

\section{Acknowledgements}

The authors appreciate Dr Adeniran of University of Abuja for his contribution towards partial completion of the project.

\section{Competing interests}

The authors declared that no competing interests exist.

\section{Authors' contributions}

A.O.T.A. designed and supervised the study, L.D.M. carried out the study and wrote the first draft of the manuscript, and F.O.B. supervised the project, interpreted the result and revised the manuscript for publication.

\section{Ethical consideration}

This article followed all ethical standards for research without direct contact with any human or animal subjects.

\section{Funding information}

The authors appreciate the Directorate Research and Development, University of the Free State, South Africa for funding the research work (Grant No. 211427604). 


\section{Data availability}

The authors confirm that the data supporting the findings of this study are available within the article.

\section{Disclaimer}

The views and opinions expressed in this article are solely those of the authors and do not reflect the official position of the affiliated institution.

\section{References}

Afifah, S.N., Ibrahim, D., Sulaiman, S.F. \& Zakaria, N.A., 2012, 'Inhibition of Klebsiella pneumoniae ATCC 13883 cells by hexane extract of Halimeda discoidea (Decaisne) and the identification of its potential bioactive compounds', Journal of Microbiology and Biotechnology 22(6), 872-881. https://doi.org/10.4014/ jmb.1111.11053

Ali, H., Houghton, P.J. \& Soumyanath, A., 2006, 'Alpha-amylase inhibitory activity of some Malaysian plants used to treat diabetes with particular reference to Phyllanthus amarus', Journal of Ethnopharmacology 107, 449-555. https://doi. org/10.1016/j.jep.2006.04.004

Amaral, A.C.F., Gomes, L.A., Silva, J.R., Ferreira, J.L.P., Ramos, A.S., Rosa, M.S.S. et al., 2014, 'Liposomal formulation of Turmerone-rich hexane fractions from Curcuma longa enhances their antileishmanial activity', BioMed Research Internationa 694934, 1-8. https://doi.org/10.1155/2014/694934

Balogun, F.O. \& Ashafa, A.O.T., 2016, 'Antioxidant, hepatoprotective and ameliorative potentials of aqueous leaf extract of Gazania Krebsiana (Less) against carbon tetra chloride $\left(\mathrm{CCl}_{4}\right.$ )-induced liver injury in Wistar rats', Transaction of the Royal Society of South Africa 71(2), 145-156. https://doi.org/10.1080/0035919X.2016.1176967

Balogun, F.O., Tshabalala, N.T. \& Ashafa, A.O.T., 2016, 'Antidiabetic medicinal plants used by the Basotho tribe of Eastern Free State: A review', Journal of Diabetes Research 2016 Article ID 4602820. https://doi.org/10.1155/2016/4602820

Barbara, G., 2014, 'Isolation and characterization of the bioactive compounds in the stem bark of Albizia coriaria', Masters dissertation, Makerere University, Kampala.

Chandrasekar, T., Rao, M.R.K., Kumar, R.V., Prabhu, K., Kumar, S.N. \& Divya, D., 2015, 'GC-MS analysis, antimicrobial, antioxidant activity of an Ayurvedic medicine, Nimbapatradi Choornam', Journal of Chemical and Pharmaceutical Research 7(8), 124-136.

Chatterjee, S., Khunti, K. \& Davies, M.J., 2017, 'Type 2 diabetes', The Lancet 389, 2239-2251. https://doi.org/10.1016/S0140-6736(17)30058-2

Cornish-Bowden, A., 2013, 'Fundamentals of enzyme kinetics', John Wiley \& Sons, London.

Dinis, T.C.P., Madeira, V.M.C. \& Almeida, L.M., 1994, 'Action of phenolic derivatives (acetaminophen, salycilate and 5-aminosalycilate) as inhibitors of membrane lipid peroxidation and as peroxyl radical scavengers', Archive of Biochemistry and Biophysics 315, 161-169. https://doi.org/10.1006/abbi.1994.1485

Dnyaneshwar, M.N. \& Archana, R.J., 2013, 'In vitro inhibitory effects of Pithecellobium dulce (Roxb.) Benth. seeds on intestinal $\alpha$-glucosidase and pancreatic $\alpha$-amylase', Journal of Biomedical Technology 4(3), 616-621.

Elsnoussi, A.H.M., Mohammad, J.A.S., Lee, F.A., Amirin, S., Sue, H.C., Soo, C.T. et al., 2012 , 'Potent $\alpha$-glucosidase and $\alpha$-amylase inhibitory activities of standardized $50 \%$ ethanolic extracts and sinensetin from Orthosiphon stamineus Benth as antidiabetic mechanism', BioMed Central Complementary and Alternative Medicine 12, 176. https://doi.org/10.1186/1472-6882-12-176

Gawli, K. \& Lakshmidevi, N., 2015, 'Antidiabetic and antioxidant potency evaluation of different fractions obtained from Cucumis prophetarum fruit', Pharmaceutical Biology 53(5), 689-694. https://doi.org/10.3109/13880209.2014.937503

Gideon, V.A., 2015, 'GC-MS analysis of phytochemical components of Pseudoglochidion anamalayanum Gamble: An endangered medicinal tree', Asian Journal of Plan Science Research 5(12), 36-41.

Grobler, A., 2010, Elephantorrhiza elephatina, SANBI The PlantZAfrica.com, viewed 20 May 2021, from http://pza.sanbi.org/elephantorrhiza-elephantina.

He, F. \& Zuo, L., 2015, 'Redox roles of reactive oxygen species in cardiovascular diseases', International Journal of Molecular Sciences 16, 27770-27780. https:// doi.org/10.3390/ijms161126059

International Diabetes Federation, 2015, IDF Diabetes Atlas, 7th edn., viewed October 2017, from http://www.diabetesatlas.org/.

Kazeem, M.I. \& Ashafa, A.O.T., 2015, 'In-vitro antioxidant and antidiabetic potentials of Dianthus basuticus Burtt Davy whole plant extracts', Journal of Herbal Medicine 5, 158-164. https://doi.org/10.1016/j.hermed.2015.06.003

Kumar, V., Bhatnagar, A.K. \& Srivastava, J.N., 2011, 'Antibacterial activity of crude extracts of Spirulina platensis and its structural elucidation of bioactive compound', Journal of Medicinal Plants Research 5(32), 7043-7048. https://doi. org/10.5897/JMPR11.1175

Kuppuswamy, M.K., Jonnalagadda, B., Arockiasamy, S., 2013, 'GC-MS Analysis of chloroform extract of Croton bonplandianum', International Journal of Pharmacology and Biological Sciences 4(4), 613-617.
Kwon, Y.I., Apostolidis, E., Kim, Y.C. \& Shetty, K., 2007, 'Health benefits of traditional corn, beans and pumpkin: In vitro studies for hyperglycemia and hypertension management', Journal of Medicinal Foods 10, 266-275. https://doi.org/10.1089/ jmf.2006.234

Larijani, B. \& Forozandeh, F., 2003, 'Diabetes foot disorders', Iranian Journal of Diabetes Metabolism 2, 93-103.

Liguori, I., Russo, G., Curcio, F., Bulli, G., Aran, L., Della-Morte, D. et al., 2018, 'Oxidative stress, aging, and diseases', Clinical Interventions in Aging 13, 757-772. https:// doi.org/10.2147/CIA.S158513

Lobo, V., Patil, A., Phatak, A. \& Chandra, N., 2010, 'Free radicals, antioxidants and functional foods: Impact on human health', Pharmacognosy Review 4(8), 118-126. https://doi.org/10.4103/0973-7847.70902

Maiti, R., Jana, D., Das, U.K. \& Ghosh, D., 2004, 'Antidiabetic effect of aqueous extract of seed of Tamarindus indica in streptozotocin-induced diabetic rats', Journal of Ethnopharmacology 92, 85-91. https://doi.org/10.1016/j. jep.2004.02.002

Manohar, V., Talpur, N.A., Echard, B.W., Lieberman, S. \& Preuss, H.G., 2002, 'Effects of a water-soluble extract of maitake mushroom on circulating glucose/insulin concentrations in KK mice', Diabetes Obesity and Metabolism 4, 43-48. https:// concentrations in KK mice', Diabetes Obesity
doi.org/10.1046/j.1463-1326.2002.00180.x

Maroyi, A., 2017, 'Elephantorrhiza elephantina: Traditional uses, phytochemistry and pharmacology of an important medicinal plant species in southern Africa', Evidence-Based Complementary and Alternative Medicine 2017, 18. https://doi. org/10.1155/2017/6403905

Mitova, M., Taskova, R., Popov, S., Berger, R.G., Krings, U. \& Handjieva, N., 2011 'GC/MS analysis of some bioactive constituents from Carthamus lanatus L.', Zeitschrift Für Naturforschung 58(9-10), 697-703. https://doi.org/10.1515/znc2003-9-1018

Mpofu, S.J., Msagati, T.A.M., Krause, R.W.M., 2014, 'Cytotoxicity, phytochemical analysis and antioxidant activity of crude extracts from rhizomes of Elephantorrhiza elephantina and Pentanisia prunelloides', African Journal of Traditional and Complementary Alternative Mediciene 11(1), 34-52. https://doi.org/10.4314/ ajtcam.v11i1.6

Narkhede, M.B., Ajimire, P.V., Wagh, A.E., Manoj, M. \& Shivashanmugam, A.T., 2011 'In vitro antidiabetic activity of Caesalpina digyna (R.) methanol root extract', Asian Journal of Plant Science Research 1(2), 101-106.

Natarajan, V., 2015, 'Isolation and characterization of anti-diabetic compound from Leptadenia reticulate [w\&a] leaf', Integrative Obesity and Diabetes 1(2), 36-40. https://doi.org/10.15761/IOD.1000109

National Library of Medicine, 2020, 2_4-Di-tert-buty/phenol, viewed 01 December 2020, from https://pubchem.ncbi.nlm.nih.gov/compound/2_4-Di-tert-butylphenol.

Olaokun, O.O., Alaba, A.E., Ligege, K. \& Mkolo, N.M., 2020, 'Phytochemical content, antidiabetes, anti-inflammatory antioxidant and cytotoxic activity of leaf extracts of Elephantorrhiza elephantina (Burch.) Skeels', South African Journal of Botany 128, 319-325. https://doi.org/10.1016/j.sajb.2019.11.030

Pieme, C.A., Tatangmo, J.A., Simo, G. Biapa Nya P.C., Ama Moor V.J., Moukette, B.M et al., 2017, 'Relationship between hyperglycemia, antioxidant capacity and some enzymatic and non-enzymatic antioxidants in African patients with type 2 diabetes', BMC Research Notes 10, 141. https://doi.org/10.1186/s13104-0172463-6

Re, R., Pellegrini, N. \& Proteggente, A., 1999, 'Antioxidant activity applying an improved ABTS radical cation decolourisation assay', Free Radical Biology and Medicine 26, 1231-1237. https://doi.org/10.1016/S0891-5849(98)00315-3

Saha, M.R., Hasan, S.M.R., Akter, R., Hossin, M.M., Alam, M.S., Alam, M.A., et al., 2008 , 'In vitro free radical scavenging activity of methanol extract of the leaves of Mimusops elengi Linn', Bangladesh Journal of Veterinary Medicine 6, 197-202. https://doi.org/10.3329/bjvm.v6i2.2336

Satlisha, A.D., Lingaraju, H.B. \& Sham Prasad, K., 2011, 'Evaluation of antioxidant activity of medicinal plant extracts produced for commercial purpose', European Journal of Chemistry 8(2), 882-886. https://doi.org/10.1155/2011/693417

Simin, K., Ali, Z., Khalid-Uz-Zaman, S.M. \& Ahmad, V.U., 2000, 'Structure and biological activity of a new rotenoid from Pongamia pinnata', Natural Product Letters 10(5), 351-357. https://doi.org/10.1080/10575630290033114

Sindhu, M. \& Emilia, A.T., 2005, 'In vitro antioxidant activity and scavenging effects of Cinnamonium verum leaf extract assayed by different methodologies', Food and Chemical Toxicology 44, 198-206. https://doi.org/10.1016/j.fct.2005.06.013

Slantchev, K., Yalçın, F., Ersöz, T., Nechev, J., Çalış, I., Stefanov, K. et al., 2002, 'Composition of lipophylic extracts from two tunicates, Styela sp. and Phallusia sp. from the Eastern Mediterranean', Zeitschrift Für Naturforschung C 57(5-6), 534-540. https://doi.org/10.1515/znc-2002-5-623

Szalay, J., 2016, 'What are free radicals?', Live science, viewed 14 March 2018, from https://www.livescience.com/54901-free-radicals.html.

Tshabalala, N.T. \& Ashafa, A.O.T., 2011, 'Ethnobotanical survey of Sotho medicinal plants used in the management of diabetes in the eastern Free State, South Africa', [Honours dissertation], Department of Plant Sciences, University of the Africa', [Honours dissertation], Depar

Wagh, P., Rai, M., Deshmukh, S.K. \& Durate, M.C.T., 2007, 'Bio-activity of oils of Trigonella foenum-graecum and Pongamia pinnata', Africa Journal of Trigonella foenum-graecum and
Biotechnology 6(13), 1592-1596.

Yang, J.F., Liang, M.T., Yang, C.H., Gao, Z.J., Wu, Y.W. \& Chuang, L.Y., 2016 'Chromatographic-mass spectrometric analysis of ethanol extract of Maesa 'Chromatographic-mass spectrometric analysis of ethanol extract of Maesa
perlaria var formosana', Tropical Journal of Pharmaceutical Research 15(5), 1025-1029. https://doi.org/10.4314/tjpr.v15i5.18 
Yayli, N., Gulec, C., Ucuncu, O., Yasar, A., Ulker, S., Coskuncelebi, K. et al., 2006, 'Composition and antimicrobial activities of volatile components of Minuartia meyeri', Turkish Journal of Chemistry 30, 71-76.

Yin, Z., Zhang, W., Feng, F., Zhang, Y. \& Kang, W., 2014, ' $\alpha$-Glucosidase inhibitors isolated from medicinal plants', Food Science and Human Wellness 3, 136-174. https://doi.org/10.1016/j.fshw.2014.11.003
Yogeswari, S., Ramalakshmi, S., Neelavathy, R. \& Muthumary, J., 2012, 'Identification and comparative studies of different volatile fractions from Monochaetia kansensis by GCMS', Global Journal of Pharmacology 6(2), 65-71.

Young, I.S. \& Woodside, J.V., 2001, 'Antioxidants in health and disease', Journal of Clinical Pathology 54, 176-186. https://doi.org/10.1136/jcp.54.3.176 